the Birmingham findings. The overall pneumonia rate in Birmingham was higher $(40 \%)$ than in Glasgow $\left(26^{\circ}\right.$ ), where pneumonia was taken to mean either consolidation on chest radiograph or a chest infection which in the judgment of the attending physician required antibiotics. It would be interesting to know what "confirmation" by chest radiography means in the Birmingham study, since the difference may be explained by differing definitions.

We have been reluctant to draw definite conclusions from the complication rate in those children immunised against pertussis compared with those not immunised, since the numbers are small, and this may also apply to the Birmingham study. However, overall findings are similar, confirming that whooping cough still causes substantial numbers of hospital admissions for a prolonged and unpleasant illness and that immunisation appears to protect children from being admitted to hospital with the disease, either by preventing it altogether or by preventing serious complications.

University Department of

Infectious Diseases,

Ruchill Hospital,

' Walker E. Communicable Diseases (Scotland) Weekly Bulletin $1979 ; 46$ :vii

IW, Love WC, Chaudhuri AKR Datta JB. Journal of Infection (in press).

\section{Is coeliac disease underdiagnosed?}

SIR,-Not only is coeliac disease underdiagnosed, as suggested by Drs Christine $M$ Swinson and A J Levi (8 November, p 1258), but there is no accurate knowledge of its prevalence throughout the United Kingdom. Facts on the numbers, age distribution, etc, of coeliacs are essential not only to establish long-term medical complications (for example, lymphoma) but also to identify changes in the incidence, as a basis for recognising environmental factors which lead to the expression of the disease in genetically predisposed individuals. Moreover, as the treatment is life long there are financial and sociological implications for the patient and the National Health Service. With the support of the Scottish Home and Health Department and with the co-operation of all the physicians, paediatricians, and pathologists in the hospitals of Lothian Region, a project to establish a register of all coeliac patients in Lothian Region has been initiated. ${ }^{1}$ As yet the data are incomplete, but it is likely that the prevalence will exceed 1 in 1100.

A search of pathology department records for jejunal biopsies typical of coeliac disease has been used as one of the ways of identifying patients. As part of the project jejunal biopsies from all supposed coeliacs are being reviewed by three of the pathologists in the region. This has been completed for the Western General Hospital and our positive biopsy rates for recent years are very comparable with the Northwick Park experience (see table below)

The gastrointestinal unit has been established at this hospital since 1949 and currently some 1000 new outpatients with gastrointestinal disease are seen each year. Until 1975 jejunal biopsy was done on an inpatient basis. Since 1976 we have used a day-bed area (as described by Rainey and Buckley ${ }^{1}$ ) the procedure being performed by gastrointestinal investigation nurses. This has greatly facilitated the investigation of patients with malabsorption or diarrhoeal disease. It is most unusual for patients suspected of coeliac disease to be admitted, and we rarely perform investigations such as tests for faecal fats in such cases. The use of the day-bed area also makes it easie to arrange the repeat biopsies necessary for. the confirmation of diagnosis by gluten exclusion and challenge.

In view of the similar "positive biopsy rates" we attempted to compare our diagnosis rate in relation to new patients with that at Northwick Park Hospital. The Lothian Health Board publishes separate figures for new general medical outpatients and for new referrals to gastrointestinal, haematological, and other specialist outpatient clinics. In the Western General Hospital we felt that a combination of new general medical outpatients and new gastrointestinal and new haematological patients would be comparable to the Northwick Park category. Over the threeyear period 1976-1978 this gave a mean diagnosis rate in new outpatients of 1 in 209.

We do not feel that it is reasonable to place too much significance on this result because the known specialist interest in any hospital will influence the pattern of referral. The membership of the Coeliac Society fails to provide an accurate indication of the prevalence of the disease in Scotland. We estimate that there are around 650 living coeliacs in the Lothians and current membership of the local branch is around 150. Recent and future recruitment to the society may however reflect an increasing awareness of this underdiagnosed condition.

EDITH A RIFKIND

A Busuttil

University Gastrointestinal Unit,

ANNE FERGUSON

Western General Hospital

' Logan RFA, Rifkind EA, Ferguson A. In: McConnell $\mathrm{RB}$, ed. The genetics of coeliac disease. Lancaster:

2 Rainey JB, Ruckley CV. Br Med J 1979; ii :714-7.
Results of biopsies in relation to coeliac disease at Western General Hospital, Edinburgh

\begin{tabular}{|c|c|c|c|c|c|c|c|}
\hline & & $\begin{array}{c}\text { Small* } \\
\text { intestinal } \\
\text { biopsies }\end{array}$ & $\begin{array}{c}\text { Number } \\
\text { diagnostic } \\
\text { of coeliac } \\
\text { diseaset }\end{array}$ & $\begin{array}{c}\text { Positive } \\
\text { diagnostic } \\
\text { biopsy } \\
\text { rate }\end{array}$ & $\begin{array}{l}\text { Number diagnostic of } \\
\text { coeliac disease } \\
+ \text { severe villous atrophy } \\
+ \text { partial villous atrophy }\end{array}$ & $\begin{array}{c}\text { Abnormal } \\
\text { biopsy } \\
\text { rate }\end{array}$ & $\begin{array}{l}\text { New } \\
\text { cases }\end{array}$ \\
\hline \begin{tabular}{|l|}
1962 \\
1963 \\
\end{tabular} & $\because$ & $\begin{array}{l}45 \\
89 \\
\end{array}$ & $\begin{array}{l}4 \\
7 \\
\end{array}$ & $\begin{array}{l}1: 11 \cdot 3 \\
1: 12 \cdot 7\end{array}$ & $\begin{array}{r}8 \\
10\end{array}$ & $\begin{array}{l}1: 7.5 \\
1: 8.9\end{array}$ & $\begin{array}{l}3 \\
5\end{array}$ \\
\hline $\begin{array}{l}1967 \\
1968 \\
\end{array}$ & $\because$. & $\begin{array}{r}72 \\
114 \\
\end{array}$ & $\begin{array}{r}8 \\
14 \\
\end{array}$ & $\begin{array}{l}1: 9 \\
1: 8 \cdot 1\end{array}$ & $\begin{array}{l}14 \\
24\end{array}$ & $\begin{array}{l}1: 5 \cdot 1 \\
1: 4 \cdot 6\end{array}$ & $\begin{array}{r}3 \\
10\end{array}$ \\
\hline $\begin{array}{l}1972 \\
1973 \\
\end{array}$ & $\because$. & $\begin{array}{r}95 \\
107 \\
\end{array}$ & $\begin{array}{r}9 \\
18 \\
\end{array}$ & $\begin{array}{l}1: 10 \cdot 6 \\
1: 5.9\end{array}$ & $\begin{array}{l}28 \\
28\end{array}$ & $\begin{array}{l}1: 3.3 \\
1: 3.8\end{array}$ & $\begin{array}{l}11 \\
15\end{array}$ \\
\hline $\begin{array}{l}1977 \\
1978\end{array}$ & $\therefore$ & $\begin{array}{l}231 \\
231\end{array}$ & $\begin{array}{l}30 \\
29\end{array}$ & $\begin{array}{l}1: 7 \cdot 7 \\
1: 7 \cdot 9\end{array}$ & $\begin{array}{l}70 \\
67\end{array}$ & $\begin{array}{l}1: 3 \cdot 3 \\
1: 3 \cdot 4\end{array}$ & $\begin{array}{l}19 \\
18\end{array}$ \\
\hline
\end{tabular}

*Biopsies carried out for inflammatory, neoplastic, and ulcerative small intestinal conditions are excluded. Biopsie include adult and paediatric cases from the North Lothian District of Lothian Health Board. +Will comprise biopsies from all new cases; also variable proportion of follow-up biopsies in treated and untreated
patients.

\section{Prevention of mumps}

SIR,-Your leading article (8 November, p 1231) voices reservations about mumps vaccination that were weighed before the vaccine was introduced. It states the overwhelmingly positive American experience, which did not verify these reservations after 40 million doses and 13 years of routine immunisation. Yet it ignores this experience when it comes to outlining policy for a European country.

It should not be inferred that an upward trend in age distribution of mumps following vaccination is associated with higher incidence in older age groups. In the American sample quoted in the leading article, ${ }^{1}$ the slight upward trend in 1972-6 compared with 1967-71 was in fact associated with reduction of incidence at all ages, and by $55 \%$ in those over 15 years old. An upward trend in age distribution almost necessarily develops when a new vaccine is introduced well before the age of peak incidence of a disease, and it could be seen even when vaccination would not affect circulation of the agent. Confusion between these distinct indices, proportion of all cases contributed by an age group and incidence at that age, also plagues the discussion about measles vaccination. ${ }^{2}$

Increased incidence at higher age could be predicted if protection wanes years after vaccination, and a most reassuring aspect of the American experience is that protection and antibodies ${ }^{3}$ did not wane. Under certain conditions childhood vaccination that gives permanent protection could result in higher incidence after puberty. It would be due to delayed exposure of non-immune individuals who did not take the vaccine or in whom the vaccine did not take, and it would probably be a temporary phenomenon preceding the expected decrease. Apparently, these conditions are not easily realised, since such an increase over prevaccination levels has not been observed in the large American experience with mumps and measles vaccines (the opposite was seen), and there is no real proof of it in other developed countries. If this trend developed in any country, public health authorities could readily reverse it by improved vaccination.

The argument that mumps is generally mild is offset by the number of cases. Hard epidemiological evidence is difficult to gather, but sources concur that at least one person out of two will be ill in his lifetime owing to mumps virus, and many more can infect others. The illness load due to mumps and its many complications, benign as they usually but not always are, is therefore considerable. The economic justification for mumps vaccination is evident if, for example, one weighs school absenteeism and its related cost, the hospitalisation rate of about $1 \%$ in European countries, 5 and total cost of mumps after puberty.

The slow pace at which European countries recommend general mumps vaccination probably owes more to the fear that adding another vaccine to the package might have an adverse affect on the acceptance of other vaccines than to reservations about community effects of mumps vaccination. There is, however, little reason for this fear. Mumps vaccine is among the least "reactogenic" of all vaccines, and it can be associated inconspicuously with other vaccinations. It is not contested that mumps vaccination is a boon for the individual, and only beneficial effects on the community 
have been shown so far. Given all this, why not vaccinate and try to vaccinate well?

The Health Council of Sweden has just recommended general vaccination with triple measles-mumps-rubella vaccine at the age of 18 months, as well as vaccination with triple vaccine of 12-year-old boys and girls. Belgium is expected to recommend shortly routine vaccination against measles and mumps at the age of 15 months, and vaccination of older children who have not had the vaccine or the disease. The Federal Republic of Germany (since 1976) and Canada have also joined the United States in recommending routine mumps vaccination of young children.

Rega Institute,

B-3000 Leuven, Belgium

${ }^{1}$ Hayden GF, Preblud SR, Orenstein WA, Conrad JL.

${ }^{2}$ Desmyter J, Krugman S. Br Med F 1980;281:1185-6.

${ }^{3}$ Weibel RE, Bunyak EB, McLean AA, Hilleman MR. Proc Soc Exp Biol Med 1979;162:328-32.

Feldman HA. In: Evans AS, ed. Viral infections of humans. London: J Wiley and Sons, 1976:317-36.

${ }_{6}^{5}$ Harasek G. Wien Kiln Wochenshr 1978;90:7-10.
6 van der Veen J. Ned Tijdschr Geneesk 1979;123:714-5.

\section{Long-term follow-up of mothers who received high doses of stilboestrol and ethisterone in pregnancy}

SIR,-The report by Dr Valerie Beral and Linda Colwell (25 October, p 1098) linking oestrogen therapy during pregnancy with later appearance (after 18-22 years) of breast cancer prompted us to review studies on oral contraceptives. Most studies have found no increase of breast cancer in oral contraceptive users and perhaps even a decrease. A delayed appearance of breast cancer, such as that noted by these authors, might have been missed because younger women predominated in these investigations.

The table summarises data from case-control studies of breast cancer and categorises them according to "young" and "old" subgroups. Only those studies which presented the relevant information in terms of patients' ages are included. It should. be noted that age categories differ among studies and that for two studies we assumed that premenopausal patients were younger than postmenopausal. The relative risks refer to breast cancer in women with any history of oral contraceptive use (ever use) compared with controls who have never used them. The study by Jick et $a l^{5}$ is an exception in that present and past users were evaluated separately.

The data in the table indicate an increased positive history of oral contraceptive use but only after they have passed into their fifth or sixth decade. Breast cancer is common in women in their later years; a small increase in risk would therefore mean a large increase in the absolute number of cases. Most oral contraceptive users have not yet reached the Pediatrics 1978;62:965-9. risk of breast cancer among women with a

critical age. Future studies should address this potential problem.

Pharmacology Section,

Michael A Vance Northeastern University

Division of Toxicology,

Johns Hopkins University

School of Hygiene and Public Healt

Baltimore, Maryland, USA

1 Fasal E, Paffenbarger J. $\mathcal{F}$ Nat Cancer Inst 1975;55:

767-73.
Brinton LA, Williams RR, Hoover RN, Stegens NL, Feinleib M, Fraumeni JF. $\mathcal{J}$ Nat Cancer Inst 1979;62:37-44.

${ }^{3}$ Vessey MP, Doll R, Jones K, McPherson K, Yeates D. Br Med $\mathcal{f} 1979 ;$;i: 1757-60.

Paffenbarger RS, Kampert JB, Chang H-G. Am J

Epidemiol 1980;112:258-68.

1980;112:577-85.

SIR,-Although the study of Dr Valerie Beral and Linda Colwell (25 October, p 1098) provides valuable data on long-term effects following administration of massive doses of stilboestrol and ethisterone to pregnant diabetics, the article is marred by an invalid comparison of the breast cancer risk found in their patients with that in postmenopausal women exposed to oestrogen therapy. We appreciate the pivot of their argument-that oestrogen exposure increases the risk of breast cancer and that the induction period may be as long as $18-20$ years-but the comparison made in this paper is inappropriate for the following reasons.

Firstly, the pregnant diabetics were prescribed ethisterone and stilboestrol, a synthetic oestrogen, whereas climacteric women are usually treated with "natural oestrogens." Synthetic oestrogens are regarded as unsuitable for alleviating climacteric symptoms because of their more pronounced adverse effects on blood coagulation and lipid and lipoprotein concentrations, and they have been shown to be at least 70 and perhaps 100 times more potent than natural oestrogens on a weight-for-weight basis in the human female ${ }^{12}$ as Helgason et $a l^{1}$ and Judd (at Round-table Conference on the Role of Progestins in Replacement Therapy, New York, 1979) have shown. Secondly, the daily dosage of stilboestrol in this study $(0.5 \mathrm{mg})$ would be considered massive if given to postmenopausal women and the mean dose administered to the pregnant diabetics $(16.3 \mathrm{~g})$ would be equivalent to 119 years of cyclical or 89 years of continuous oestrogen use in postmenopausal women. Although commenting on differences in dosage Dr Beral and Ms Colwell failed to consider the relative potencies of synthetic and natural oestrógens; when these are taken into account the dosage of stilboestrol given to the pregnant diabetic becomes equivalent io many hundreds of years of postmenopausal oestrogen exposure.

Thirdly, the authors' inference that a causal relationship exists between postmenopausal oestrogen use and breast cancer is not sup-

Relative risk of breast cancer in women with a history of contraceptive use compared with controls in published studies

\begin{tabular}{|c|c|c|c|c|c|c|c|}
\hline \multirow[b]{2}{*}{ Reference } & \multicolumn{2}{|c|}{ Definition (y) } & \multicolumn{2}{|c|}{ No of cases } & \multicolumn{3}{|c|}{ Relative risk } \\
\hline & Young & Old & Young & Old & Young & Old & OC use \\
\hline $\begin{array}{l}1 \\
2 \\
3 \\
4 \\
5 \\
5\end{array}$ & $\begin{array}{l}15-39 \\
\text { pre } \\
16-40 \\
\text { pre } \\
31-45 \\
31-45\end{array}$ & $\begin{array}{l}40-49 \\
\text { post } \\
46-50 \\
\text { post } \\
46-55 \\
46-55\end{array}$ & $\begin{aligned} 104 \\
126 \\
301 \\
768 \\
31 \\
23\end{aligned}$ & \begin{tabular}{r|}
348 \\
160 \\
115 \\
1090 \\
24 \\
26
\end{tabular} & $\begin{array}{l}0.72 \\
0.80 \\
0.8 \\
1.09 \\
1.2 \\
0.8\end{array}$ & $\begin{array}{l}1.31 \\
1.66 \\
2.4 \\
1.24 \\
3.2 \\
8.0\end{array}$ & $\begin{array}{l}\text { Ever } \\
\text { Ever } \\
\text { Ever } \\
\text { Ever } \\
\text { Past } \\
\text { Present }\end{array}$ \\
\hline
\end{tabular}

Pre = premenopausal; post $=$ postmenopausal $; O C=$ oral contraceptive . ported by the published data and only three of the 12 relevant studies have reported a positive association. The study of Hoover et al, ${ }^{3}$ which is quoted in a highly selective and unrepresentative manner, reported an increase in risk but no dose-dependent relationship was found. The other two studies suggesting a causal relationship are those of Casagrande et al, ${ }^{3}$ in which only 47 patients were scrutinised, and Ross et al, ${ }^{4}$ which, like most of the other epidemiological surveys, suffers from a lack of adjustment for surveillance and protopathic bias. ${ }^{5}$ Whether Dr Beral and Ms Colwell also implicate ethisterone, a progestin, in the genesis of breast cancer is unclear. We are not aware of any human studies suggesting an oncogenic role for progestin and it is more likely that they would exert an inhibitory effect on the breast analogous to that on the endometrium. ${ }^{6}$ Pregnant diabetics receiving massive doses of stilboestrol and ethisterone may be at an increased risk of developing breast cancer, but it would be unwise to extrapolate these conclusions to postmenopausal women receiving oestrogen therapy.

G LANE

NiCK SIDDLE

$M$ WhITEHEAD

Department of Obstetrics and Gynaecology,
King's College Hospital Medical School,

London SE5 8RX

${ }^{1}$ Helgason S, Damber M-G, von Schoultz B, Stig-

${ }^{2}$ Hoover R, Gray LA, Cole P, McMahon B. $N$ Engl f Med 1976;295:401.

Casagrande J, Gerkins J, Henderson BE, Mack T, Pike MC. F Nat Cancer Inst 1976;56:839.

Ross RK, Paganini-Hill A, Gerkins VR, Mack TM, Pfeffer R, Arth

Horowin Ambrus JL, eds. The menopause an Ambrus JL, eds. The menopause and postmenopause. 6 Whitehead, MI, King RJB, Campbell S. In: Proceedings of IX world congress of obstetrics and gynaecology. Amsterdam: Excerpta Medica, 1980:
$61-5$.

** We sent this letter to the authors, and $\mathrm{Dr}$

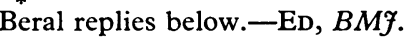

SIR,-We agree with Dr Lane and his colleagues that the evidence linking menopausal oestrogen use and breast cancer is contradictory.

Our findings, together with those from Chicago, ${ }^{1}$ offer strong evidence that when given during pregnancy high doses of stilboestrol (with or without progestogens) increase the risk of breast cancer. Furthermore, long latent periods seem to be involved. It therefore seems reasonable to suggest that if menopausal oestrogens affect breast cancer risk long latent periods may also be involved. At the time of preparing our report only Hoover et $a l^{2}$ had considered that the risk of breast cancer following menopausal oestrogen use may be altered after relatively long latent periods. They noted an increased risk of breast cancer 15 years after exposure to oestrogens. Clearly more information on menopausal oestrogens-and on "natural oestrogens" in particular-is needed; but the possibility that very long latent periods may be involved must be taken into account.

Department of Medical Statistics

VALERIE BERAL

\section{and Epidemiology, London School of Hygiene and Tropical Medicine, \\ Bibbo $M$, Haenszel WM, Wied GL, Hubby $M$, Herbst AL. N Engl Y Med 1978;298:763-7.} Hoover R, Gray LA, Cole P, MacMahon B. N Engl 